
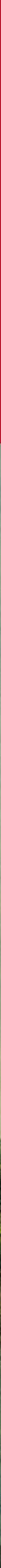


\title{
Jan Drentje
}

\section{De scheiding tussen de publieke en private sfeer}

\author{
De vriendschap tussen Willem Anne Schimmelpenninck en \\ Johan Rudolf Thorbecke
}

M.A.M. Franken, Willem Anne Schimmelpenninck van der Oije (1800-1872). Uit de schaduw van Thorbecke (Uitgeverij Matrijs: Utrecht, 2019, 184 p., ill.)

Historicus M.A.M. Franken schreef eerder verdienstelijke boeken over de Gelderse familie Schimmelpenninck van de Oije. In een biografie met als veelbetekenende ondertitel Uit de schaduw van Thorbecke, schrijft hij over Willem Anne Schimmelpenninck van der Oije (1800-1872). Willem Anne stamde uit een minder welgestelde tak van de familie, maar op zestienjarige leeftijd was hij in één klap boven Jan door een erfenis van zijn verre oom en naamgenoot. Hij werd onder andere heer van het landgoed De Poll en verkreeg kasteel Nijenbeek in Voorst. Hiermee werd hij een van meest vermogende edellieden in Gelderland en lag een carrière in het bestuur voor de hand. De wijze oom bepaalde dat Willem Anne pas op zijn 25 ste de beschikking over zijn fortuin zou krijgen. Willem Anne had aan de Koninklijke Militaire Academie te Breda gestudeerd en was officier bij de artillerie in Nijmegen geworden. $\mathrm{Nu}$ het perspectief op een leven als vermogend landheer geopend was, nam hij ontslag en besloot te gaan studeren aan de universiteit in Göttingen. Daar ontmoette hij Thorbecke die na zijn promotie in Leiden een beurs had gekregen om onder andere in Göttingen de opzet van de bibliotheek te besturen - maar zelf vooral van plan was zich te verdiepen in de filosofie.

Tussen beiden ontwikkelde zich een warme vriendschap. Thorbecke beleefde in zijn studententijd een romantische crisis, die hij op een filosofische manier te boven kwam. Franken veronderstelt dat Willem Anne zich in Göttingen ook in de romantiek heeft verdiept. Dat blijkt echter niet uit de bronnen. Göttingen was allerminst een 'romantische universiteit'. Er werd gedegen wetenschap bedreven voor studenten die een loopbaan in het bestuur na- 


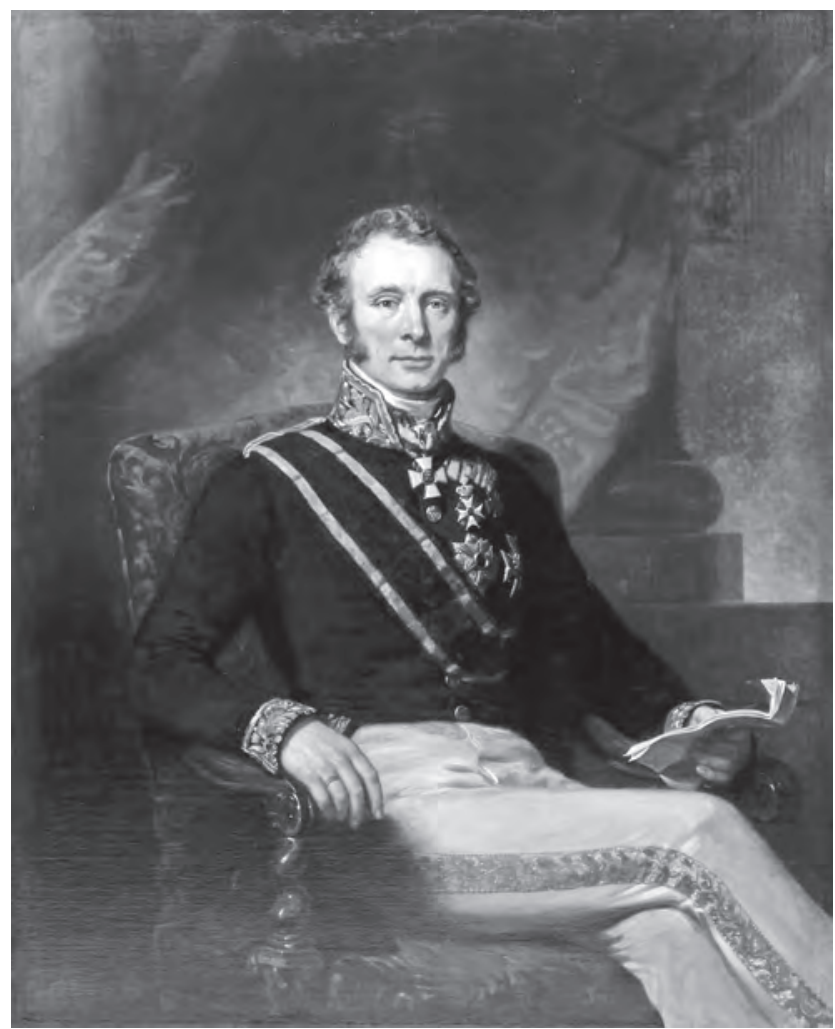

Willem Anne Schimmelpenninck van der Oije (1800-1872) (doek, Nicolaas Pieneman, 1850; Academische Erfgoedcollectie van de TU Delft Library, foto Sander van Dam)

streefden. De liefde voor de natuur van Willem Anne had, in tegenstelling tot die van Thorbecke, geen filosofische connotaties.

Thorbecke zou uitgroeien tot de bekende politicus-staatsman van 1848, het jaar van een ingrijpende grondwetsherziening. Aan Willem Anne wordt nog zelden gerefereerd, of het moet zijn vanwege deze onderlinge vriendschap - die op een lelijke manier spaak is gelopen. Vandaar dat Franken beoogt om Willem Anne uit de schaduw van Thorbecke te halen door zijn, vóór 1848 , succesvolle carrière in het openbaar bestuur uitgebreid te behandelen. Meer in het algemeen is het lot van de jaren 1840 in de geschiedschrijving nogal eens als periode van stagnatie te worden gezien, de jaren in de schaduw van 1848. Dat is het gevolg van een diachroon historisch perspectief, waarbij vooral de nadruk komt te liggen op de gebreken van het tijdvak. Bij een meer synchrone, 'eigentijdse' behandeling blijkt dat er natuurlijk ook in die jaren van alles gebeurde wat zijn waarde niet verliest vanwege het vervolg. Franken slaagt erin Willem Anne als een bekwaam minister te portretteren - zoals eerder in het werk van J.C. Boogman het succesvolle optreden van iemand als Floris Adriaan van Hall als minister van Financiën naar voren werd gehaald. Toch is de behandeling van wetgeving en maatregelen te summier om echt een afgewogen oordeel te geven over deze periode.

Uit Frankens relaas blijkt ook duidelijk hoezeer Willem Anne een representant was van de Gelderse standspolitiek. Vanwege de peperdure volhardingspolitiek van koning Willem I 
stemde hij als Tweede Kamerlid aanvankelijk tegen de begroting, wat overeenstemde met de wens van de Staten van Gelderland. Toen de koning in 1838 een vreedzame oplossing in het vooruitzicht stelde, stemde Willem Anne toch in met de begroting voor buitengewone oorlogskosten - tot verrassing van zijn liberale vrienden. Franken noemt Willem Anne in zijn jonge jaren een liberaal, maar veel meer dan een persoonlijke liberaliteit hield dit niet in. Goed beschouwd had hij geen idee van de langetermijngevolgen van de Franse Revolutie. Als minister van Binnenlandse Zaken bleek hij een overtuigd monarchist, die weinig moest hebben van constitutionele veranderingen waar juist zijn vriend Thorbecke voor pleitte.

Toch was Thorbecke verheugd over de benoeming van Willem Anne tot minister in 1841 . Hij hoopte dat de energieke edelman het verschil kon maken. Willem Anne op zijn beurt tekende meteen aan dat Thorbecke 'persoonlijk nog wel eens last' kon hebben van zijn nieuwe betrekking omdat hij 'op eigen beenen' moest staan. En zo geschiedde. Thorbecke kreeg aanvankelijk een adviserende rol, maar daar kwam in de praktijk weinig van terecht. Willem Anne legde de meeste adviezen namelijk zonder blikken of blozen naast zich neer. Dit liep uit op een regelrechte botsing toen Willem Anne bij de Tweede Kamer een nieuwe kieswet indiende die Thorbecke tevoren vertrouwelijk had mogen inzien en scherp had bekritiseerd. Hierop reageerde Thorbecke met de destijds baanbrekende brochure Over de hervorming van het kiesstelsel (1842), waarin hij de dubbel getrapte afvaardiging op basis van standen op de korrel nam. Willem Anne nam het Thorbecke zeer kwalijk dat hij in het openbaar afstand nam van zijn kieswet. Bovendien had Thorbecke hem daarover van tevoren niet ingelicht. Franken is het met Willem Anne eens. Deze manier van doen zou teruggaan op een al te 'rationele' houding van Thorbecke die de zaak (de politieke kwestie) boven de vriendschap stelde. $\mathrm{Nu}$ is het zeker zo dat Thorbecke vanaf zijn optreden in de Dubbele Kamer in 1840 het thema van constitutionele hervorming compromisloos op de agenda het gezet. Er moest naar zijn mening een fundamentele hervorming plaatsvinden. En de kieswet van Willem Anne was dat beslist niet. Anderzijds, had Willem Anne zijn vriend wel tevoren ingelicht toen hij van diens adviezen afweek? Thorbeckes antwoord aan Willem Anne maakt duidelijk dat het hem om de wetgeving ging, niet om de persoon. Willem Anne kon dit niet van elkaar scheiden, wat past in de traditionele oligarchische standspolitiek. Die scheiding tussen vriendschappelijke betrekkingen en politieke inhoud maakte daarentegen Thorbeckes rol als hervormer mogelijk.

Met de vriendschap kwam het niet meer goed. Toen in 1842 Sophie, de echtgenote van Willem Anne, overleed, schreef Thorbecke hem een warme, diep menselijke brief. Willem Anne was er dankbaar voor, maar wees er nogmaals op dat Thorbecke 'de zaken en de personen te zeer' scheidde. Toen Willem Anne in 1845 vanwege ziekte als minister moest aftreden - kort na het afwijzen van het liberale negenmannenvoorstel - kreeg hij een bijzonder liefdevolle brief van Thorbecke, waarin deze zijn 'teederheid' uitsprak voor diens persoon. Willem Anne reageerde ontwijkend en wees erop dat hij in de voorstellen van Thorbecke 'niets dan ellende voor het land' zag. Moet Thorbecke nu worden verweten dat hij geprobeerd heeft zijn gevoelens van vriendschap te redden van de onoverbrugbare politieke meningsverschillen door een scheiding hiertussen aan te brengen? Nogmaals, zonder die scheiding zou Thorbecke zijn bijzondere rol als hervormer niet hebben kunnen spelen. 
Dat blijkt ook uit de pijnlijke episode die Franken vreemd genoeg weglaat uit zijn boek. In 1852 bracht Thorbecke als hervormend minister onverwacht een werkbezoek aan Willem Anne in diens hoedanigheid van commissaris des konings in Gelderland. Aanleiding voor het bezoek waren berichten over het ontwijken van de nieuwe liberale wetgeving. Willem Anne weigerde de minister te ontvangen. Hierop heeft Thorbecke zijn oude vriend, nu een openlijke politieke tegenstander, voorgedragen voor ontslag, hetgeen de koning pas heeft ingewilligd toen Thorbecke dreigde anders zelf af te treden. Had Thorbecke een andere keuze? Als minister zou hij drie commissarissen en een flink aantal burgemeesters ontslaan die zich niet hielden aan bijvoorbeeld de scheiding tussen privézaken en hun bestuurlijke verantwoordelijkheid. De scheiding tussen enerzijds de private en anderzijds de publiekrechtelijke, openbare sfeer is een van de belangrijkste punten van de hervormingen die sinds 1848 in gang zijn gezet. Precies tegen die scheiding is de vriendschap tussen Willem Anne en Thorbecke niet bestand gebleken. 
Houses divided? Noble familial and class connections during the Age of Revolution and Napoleon

\section{Mary K. Robinson}

'Le marriage m'a toujours fait peur.' Ongehuwde adellijke vrouwen in de zeventiende en achttiende eeuw

\section{Evelyn Ligtenberg}

Steekpenning of welkomstgeschenk? De strijd voor eerherstel van Gerrit Burchard en Adolf Hendrik van Rechteren

\section{Michel Hoenderboom}

The politics of presence. Place making among the Swedish iron producers in the county of Västmanland ca. 1750-1850

Marie Steinrud

De Belgische orangistische adel, deel II. De rol van de adel in het Belgisch orangisme (1830-1850)

Els Witte 